\title{
The larva of Neoneura confundens Wasscher and van't Bosch, 2013 (Odonata, Coenagrionidae) and key to the larvae of genus
}

\author{
JOSÉ S. RODRÍGUEZ and CARLOS MOLINERI \\ Instituto de Biodiversidad Neotropical, National Council of Scientific Research/CONICET, Universidad Nacional de \\ Tucumán, Facultad de Ciencias Naturales e IML, Ciudad Universitaria Horco Molle (T4105XAY), Argentina \\ Manuscript received on March, 14, 2019; accepted for publication on May 7, 2019
}

\begin{abstract}
How to cite: RODRÍGUEZ JS AND MOLINERI C. 2019. The larva of Neoneura confundens Wasscher and van't Bosch, 2013 (Odonata, Coenagrionidae) and key to the larvae of genus. An Acad Bras Cienc 91: e20190302. DOI. 10.1590/0001-3765201920190302.

Abstract: The beautifully colored damselflies included in Neoneura Selys are divided in 28 species known from North, Central and South America. Larval stage is little known, only seven species were described at this stage. We describe and illustrate the final instar larva of Neoneura confundens for the first time. Adults associated to this larva correspond to the blue form of the species and are also discussed and illustrated. The larva of $N$. confundens is similar to other Neoneura larvae, showing 1 premental seta and a wellmarked nodus in caudal lamellae, but it can be differentiated by having fringed posterior margin in all tibiae and in middle and hind tarsi, among other characters. A key to known larvae of Neoneura and new records extending the species range in the southern cone are provided.
\end{abstract}

Key words: protoneuridae, zygoptera, immature stage, larval identification.

\section{INTRODUCTION}

The genus Neoneura Selys comprises a beautifully colored group of small damselflies known from Southwest USA to northern Argentina and Uruguay, including Brazil almost entirely (Garrison et al. 2010). Adults perform a hovering flight just above water surface under riverine canopy, rushing apart when disturbed. Contrary to the noticeable adults, larvae are almost unknown, from the 28 species described (Garrison 1999, Garrison et al. 2010, Wasscher and van't Bosch 2013) only the larvae of seven are recognized: $N$. aaroni Calvert, $N$. carnatica Selys, $N$. fulvicollis Selys, $N$. joana Williamson, N. maria, $N$. kiautai Machado and N. ethela Williamson (Westfall and May 2006, Needham 1939, De Marmels 2007, Geijskes 1954, Westfall 1964, Anjos-Santos et al. 2011, De Souza et al. 2012).

Neoneura was until recently classified in Protoneuridae (Pessacq 2008), however, Dijkstra et al. (2013, 2014) transferred all the Neotropical species of this family to Coenagrionidae. Neoneura confundens Wasscher and van't Bosch (2013) presents some variability in male coloration (green, yellow and blue

Correspondence to: Carlos Molineri

E-mail: carlosmolineri@gmail.com

ORCid: https://orcid.org/0000-0003-2662-624X 
forms) and in male cercus denticulation ( 1 to 3 ventral denticles may be present) throughout its wide distributional range, but its larva is still unknown. The aim of this work is to describe for the first time the larva of this species, presenting the first key including all species known to this stage. We also present drawings and a brief discussion on the male adults associated with these larvae. New data allow a $300 \mathrm{~km}$ southward extension of the species distributional range.

\section{MATERIALS AND METHODS}

The larvae and adults were associated by two pharate adults inside the larval cuticle (one male and one female), and one teneral male with its larval exuviae captured just after emergence. The larvae show all diagnostic characters of the genus following Wascher and van't Bosch (2013). Mandibular formula according to Watson (1956). To produce some of the pictures with enhanced quality a series of partially focused images were taken and posteriorly processed with the aid of the program CombineZP (Hadley 2010). All drawings were made using a camera lucida attached to a microscope Olympus BX51 and a stereomicroscope Nikon SMZ-10. All the specimens are preserved in $96^{\circ}$ alcohol unless otherwise stated. The material is deposited in the Instituto de Biodiversidad Neotropical (IBN, Tucumán, Argentina).

\section{RESULTS}

Neoneura confundens WASSCHER AND VAN'T BOSCH, 2013 (FIGURES 1-40)

Specimens examined. $1 \widehat{\jmath}$ (teneral) with larval exuviae, 2 larval exuviae ( $\partial$ and $q$ ), $1 \hat{\jmath} 1 q$ adults (in tandem), $1 \hat{\jmath} 19$ adults (in tandem, dried), $10 \hat{\jmath}$ adults ( 7 dried): Argentina, Tucumán, Trancas, El Boyero,

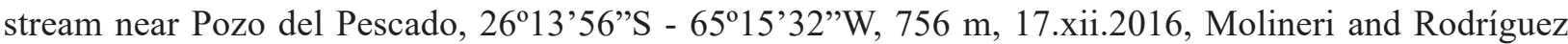
legs.. One larvae ( + immature) and 1 đ larval exuvia: Argentina, Tucumán, Simoca, Monteagudo, Río

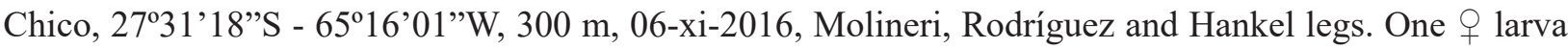
(pharate) same data as previous except date 01-xii-2016. One $\widehat{\delta}$ larva (pharate): Argentina, Santiago

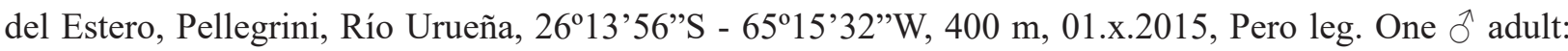
Argentina, Tucumán, Simoca, Río Seco (bridge on RN157), 27²0’11'S - 65¹9’14”W, 315 m, 03.xi.2017, Molineri and Rodríguez legs.

\section{LARVAL DESCRIPTION}

Head: wider than long, wider than thorax (Figs. 16-18), occipital lobes rounded and covered with several strong spiniform setae, posterior margin concave (Figs. 16, 17). Antennae (Figs. 16, 17, 26): with 7 segments, scape and pedicel smooth, robust and cylindrical, remaining antennomeres slender and cylindrical, antennomeres 3 to 6 with a ring of hair-like seta at distal part, antennomere 7 smooth. The third antennomere is the longest; the sixth and seventh are the shortest (Table I). Labium with prementumpostmentum articulation reaching first coxae. Prementum subtriangular (Fig. 27) longer than wide, with a V-shaped dark mark; dorsal surface with one pair of premental setae at each side of midline; ligula very prominent and convex, slightly crenulated with a row of minute spatulated setae; lateral margin of the prementum with 14-16 strong spiniform setae at medial distal portion; laterodistal margin with 2-3 strong spiniform setae. Postmentum subquadrangular, in ventral view with several scattered spiniform setae at each side of the midline. Labial palp (Figs. 28, 29) with 3-4 setae; inner margin crenulated, external margin 
TABLE I

Measurements (mm) from 5 last instar larvae. Body length does not include appendages. All the measures are lengths, unless otherwise stated.

\begin{tabular}{ccccccc}
\hline & female & female & male & male & male & Mean \\
\hline Body & 10.00 & 12.00 & 10.00 & 12.00 & 11.00 & 11.00 \\
Inner wingpads & 3.80 & 3.70 & 3.70 & 3.60 & 3.70 & 3.70 \\
External wingpads & 3.50 & 3.40 & 3.30 & 3.20 & 3.50 & 3.38 \\
Head (width) & 2.80 & - & 2.80 & - & - & 2.80 \\
Head & 1.70 & - & 1.70 & - & - & 1.70 \\
Antennomere I & 0.25 & - & 0.20 & - & - & 0.23 \\
II & 0.30 & - & 0.30 & - & - & 0.30 \\
III & 0.45 & - & 0.40 & - & - & 0.43 \\
IV & 0.30 & - & 0.30 & - & - & 0.30 \\
V & 0.20 & - & 0.15 & - & - & 0.18 \\
VI & 0.10 & - & 0.10 & - & - & 0.10 \\
VII & 0.10 & - & 0.10 & - & - & 0.10 \\
Prementum(width) & 1.75 & 1.90 & 1.65 & 1.85 & 1.80 & 1.79 \\
Prementum & 2.00 & 2.20 & 2.00 & 2.10 & 2.00 & 2.06 \\
Femur 1 & 1.70 & 1.75 & 1.60 & - & - & 1.68 \\
Femur 2 & 2.30 & 2.10 & 2.05 & - & - & 2.15 \\
Femur 3 & 2.65 & 2.50 & 2.40 & - & - & 2.52 \\
Tibia 1 & 2.20 & 2.30 & 2.00 & - & - & 2.17 \\
Tibia 2 & 2.50 & 2.30 & 2.25 & - & - & 2.35 \\
Tibia 3 & 3.00 & 2.75 & 2.45 & - & - & 2.73 \\
Lateral lamellae & 5.00 & - & 4.80 & 5.00 & - & 4.93 \\
Median lamella & 4.00 & - & 4.00 & 4.50 & - & 4.17 \\
\hline
\end{tabular}

with a row of 4-7 short spine-like setae; apical margin serrated forming four small teeth and with a strong end hook (Fig. 29); movable hook slender and pointed. Maxillae, cardo with a group of 4-7 stout spiniform setae near articulation with stipes; stipes with two piliform setae, one near the base and one near the apex, both directed anteriorly; galea with 5 strong teeth, a row of 12 strong spiniform setae directed towards the apex and several long piliform setae in external margin; lacinia pointed and covered with several piliform setae. Labrum with lateral margins rounded (Fig. 25); several spiniform and strong piliform setae at each side of the middle line. Hypopharynx: anterior surface with several thin setae, lateral lobes with 5-6 strong piliform setae, ventral surface with a row of 4-5 strong piliform setae. Mandibular formula: left mandible (Fig. 30): 1+2345 0 a b, right mandible (Fig. 31): 1+2345 y ab merged. Thorax: lateral projections rounded; wing pads parallel, reaching posterior margin of S4; legs (Figs. 32-35) long and with brownish bands on femora and tibiae, femora flattened, tibia and tarsi cylindrical. Femora with a row of 2-6 blunt short spines on extensor and flexor margins (detail of Fig. 33), extensor margin also with piliform setae (Figs. 33-35); femur I with a pair of short spatulate setae on dorsal surface (Fig. 33). Femora with brownish median band separated in the middle by a paler area (Figs. 16-18, 33-35). Tibiae with a row of long piliform setae along dorsal margin and several stout spines on ventral margin near distal apex (Figs. 32-35); tibiae with 


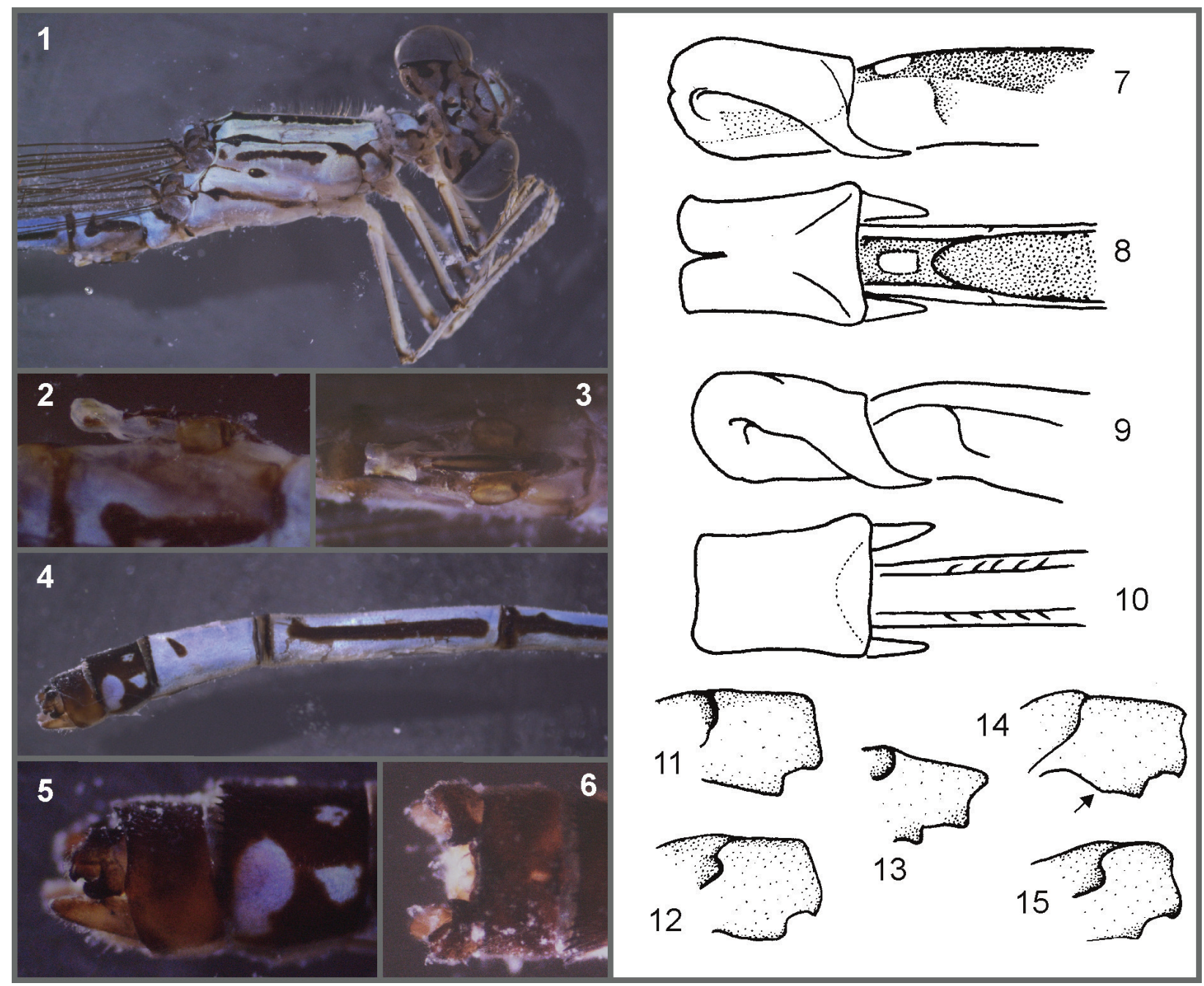

Figures 1-15 - Neoneura confundens, male adult (Argentina, Tucumán): 1, head and thorax; 2, ligula, lateral view; 3, ligula, ventral view; 4, abdominal S7-10, lateral view; $\mathbf{5}$, detail of S9-10, cercus and paraprocts, lateral view; $\mathbf{6}$, details of S10, cerci and paraprocts, dorsal view. Mature male: 7, ligula, lateral view; 8, ligula, ventral view; 11-12, cercus, inner latero-dorsal view. Teneral male: 9, ligula, lateral view; 10, ligula, ventral view; 13, cercus, inner latero-dorsal view. Mature male: 14-15, cercus, inner laterodorsal view (arrow indicates remnants of a third denticle).

a brownish band on 1/3 from base and another one at apex. Tarsi with four rows of bipectinate spiniform setae on latero-ventral surface and with row of long piliform setae on dorsal margin (except on fore tarsus) (Figs. 33-35).

Abdomen (Figs. 16-18, 36-40): almost cylindrical, narrowing posteriorly; S1-10 covered with piliform setae; lateral carina present on S1-8; lateral margins of S7-10 with few spiniform setae, and posterior margin with blunt and spiniform setae (Figs. 36-40). Male (Fig. 21) and female (Fig. 24) cerci subtriangular, short and blunt. Male gonapophyses (Figs. 37, 38) triangular, pointed and parallel; with 0 to 1 spiniform setae and several piliform setae near the base (Fig. 38). Female gonapophyses (Figs. 39, 40) parallel and surpassing posterior margin of S10; inner valves with rounded tip and smooth, outer valves sharply pointed and with a row of 3-4 spiniform setae, also with scattered piliform setae (Fig. 39). Both caudal lamellae with wellmarked nodus, basal part well sclerotized, distal part poorly sclerotized, hyaline with dark markings (Figs. 


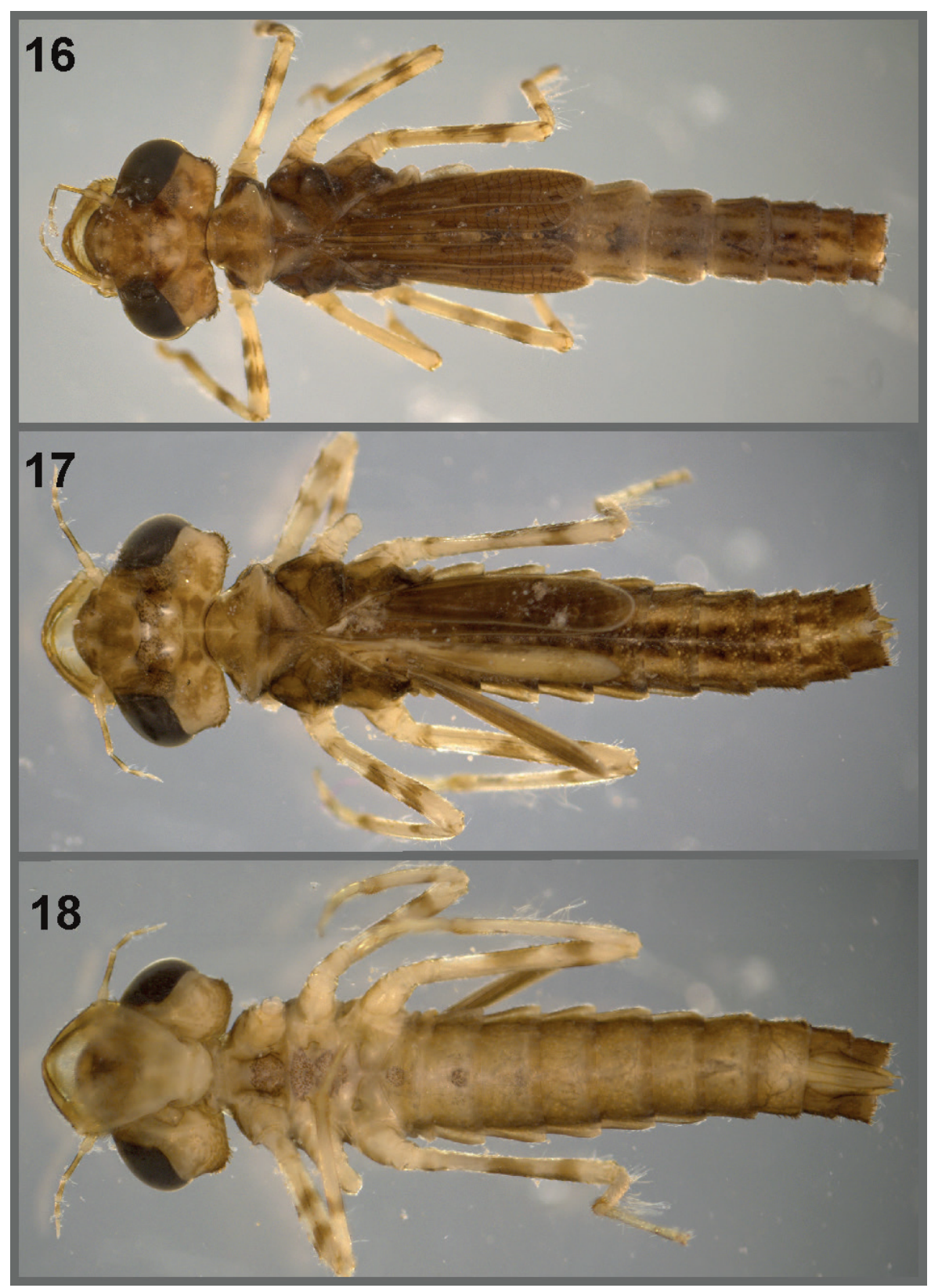

Figures 16-18 - Neoneura confundens, last instar larva, habitus: 16, male, dorsal view; 17, female, dorsal view; 18, female, ventral view.

19, 20, 22-23). Lateral lamella (Figs. 19, 22) with several short hair-like setae and 7 spiniform setae at dorsal margin, ventral margin with 26 strong spiniform setae and several short hair-like setae; external carina with 22 spiniform setae and internal carina with 9 spiniform setae; apical colorless portion with dorsal and ventral margins only with short piliform setae increasing in length distally. Central lamella (Figs. 20, 23) with 29 strong spiniform setae and several short piliform setae on dorsal margin; ventral margin with 10 strong spiniform setae and several short piliform setae; external and internal carina with 8 spiniform setae; apical colorless portion as in lateral lamella. 


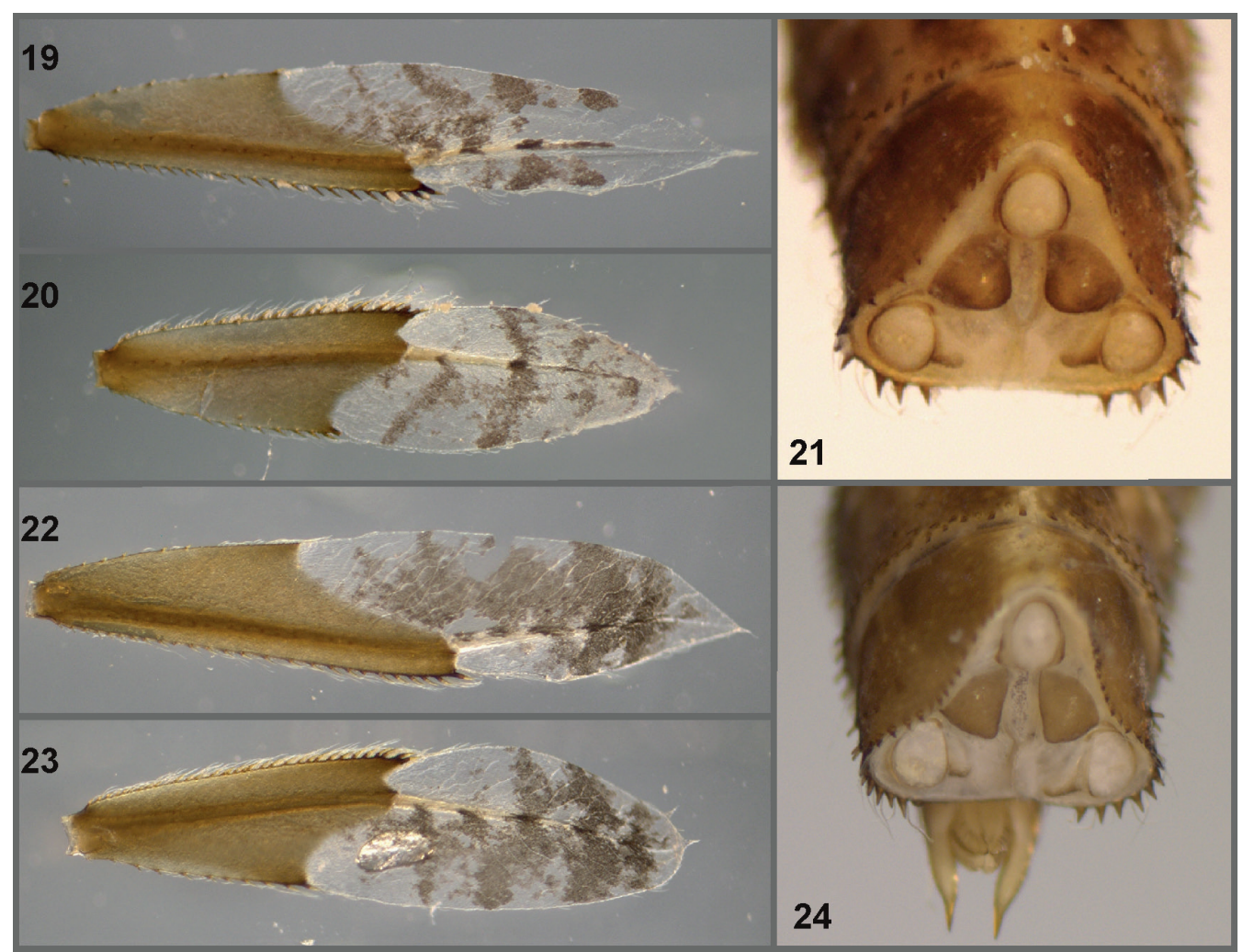

Figures 19-24 - Neoneura confundens, last instar larva. Male: 19, lateral caudal lamella; 20, median caudal lamella; 21, abdominal S10 and cerci, posterior view. Female: 22, lateral caudal lamella; 23, median caudal lamella; 24, abdominal S10 and cerci, posterior view.

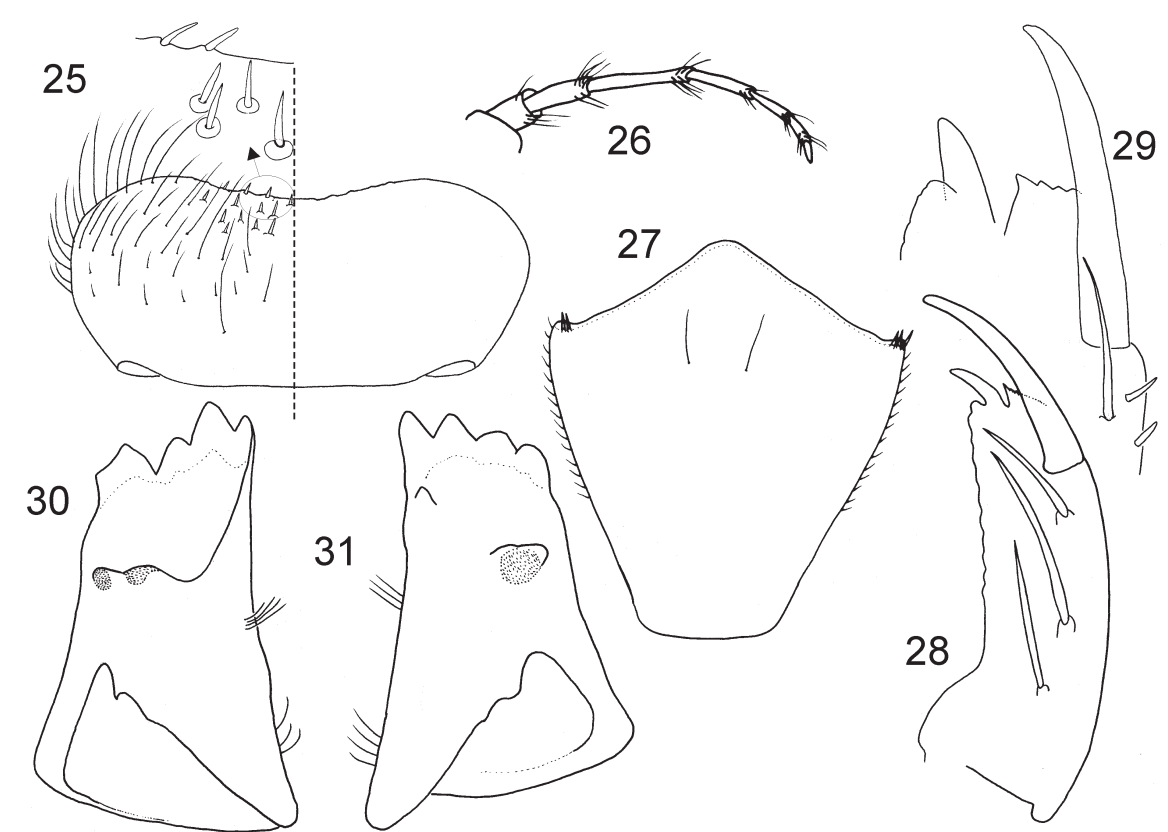

Figures 25-31 - Neoneura confundens, last instar larva: 25, labrum with detail of setae at anteromedian emargination (setae omitted on right half), dorsal view; 26, antenna; 27, prementum, dorsal view; 28, labial palp, dorsal view; 29, detail of labial palp, dorsal view; 30, left mandible, oclusal view; 31, right mandible, oclusal view. 


\section{MALE ADULT REMARKS}

All the characters coincide with the descriptions and comments provided by Wasscher and van't Bosch (2013) for the blue form of the species (Figs. 1-15). The ligula of mature (Figs. 2, 3, 7, 8) and teneral males (Figs. 9, 10) are morphologically similar. Cercus morphology falls inside the variation previously reported (Wasscher and van't Bosch 2013), two ventral denticles are present as in most known specimens (Figs. 11-15). A small insinuation of a "third" denticle is noticeably (arrow in Fig. 14) only in one cercus of one specimen from Tucumán.

\section{DISTRIBUTION AND BIOLOGY}

Neoneura confundens is known from Argentina, Bolivia, Brazil, Colombia, Ecuador, Guyana, Suriname, Trinidad, Venezuela (Wasscher and van't Bosch 2013). In Brazil this species is known in many sites on western, eastern and southern areas however, no records are known from central and lower Amazon (Wasscher and van't Bosch 2013). It is the only species occurring in NW Argentina, known from Salta (cited as N. bilinearis by von Ellenrieder and Muzón 2008) and Jujuy (Rodríguez et al. 2014). We present new records for the provinces of Tucumán and Santiago del Estero, $280 \mathrm{~km} \mathrm{~S}$ from previous records. Adults are common in the streams where larvae and exuviae were collected. We sampled areas of premontane forest in Yungas of Salta and Jujuy and they were always found flying on the banks of the rivers just above the water surface. Females were observed ovipositing alone or in tandem on emergent aquatic plants on shaded areas with slow flow. Three exuviae were found on leafs of Eichornia crassipes (Pontederiaceae) and the others in roots of terrestrial plants. Other odonate species collected in Pozo del Pescado are Enallagma novaehispaniae Calvert, 1907, Acanthagrion lancea Selys, 1876, A. floridense Fraser, 1946, Ischnura fluviatilis Selys, 1876, I. capreolus (Hagen, 1861), Oxyagrion ablutum (Calvert, 1909), O. rubidum (Rambur, 1842) (Coenagrionidae); Elasmothemis cannacrioides (Calvert, 1906), Erythemis plebeja (Burmeister, 1839) and Erythrodiplax sp. (Libellulidae); Phyllocycla argentina (Hagen in Selys, 1878), Progomphus complicatus Selys, 1854, and P. phyllochromus Ris, 1918 (Gomphidae).

\section{KEY TO THE LARVAE OF NEONEURA}

Modified from de Souza et al. (2012), three species amended. Neoneura aaroni Calvert is not included because of insufficient knowledge.

1. At least tibiae and tarsi of middle and hind legs heavily fringed with long hairs on hind margin (Figs. 34,

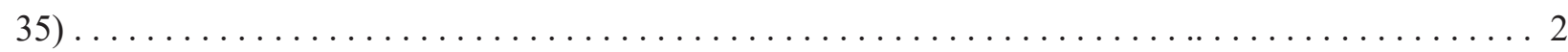

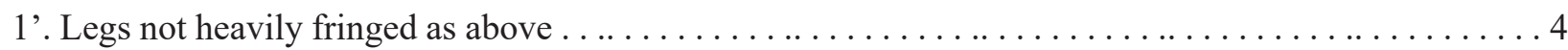

2. Three dark bands present on femora; shape of prementum semi-oval (distributed in Cuba) . . . . . . 3

2'. Two dark bands on femora (Figs. 33-35); shape of prementum triangular (Fig. 27) (distributed in

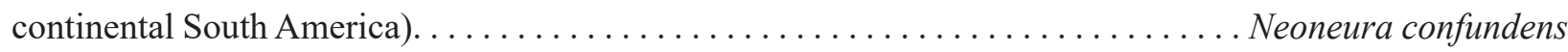

3. General coloration blackish (fresh specimens); 40-45 setae on the ventral margin of lateral lamella. . .

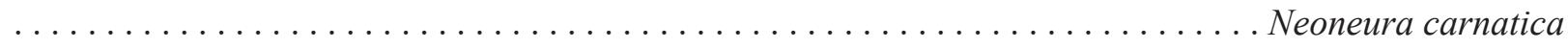




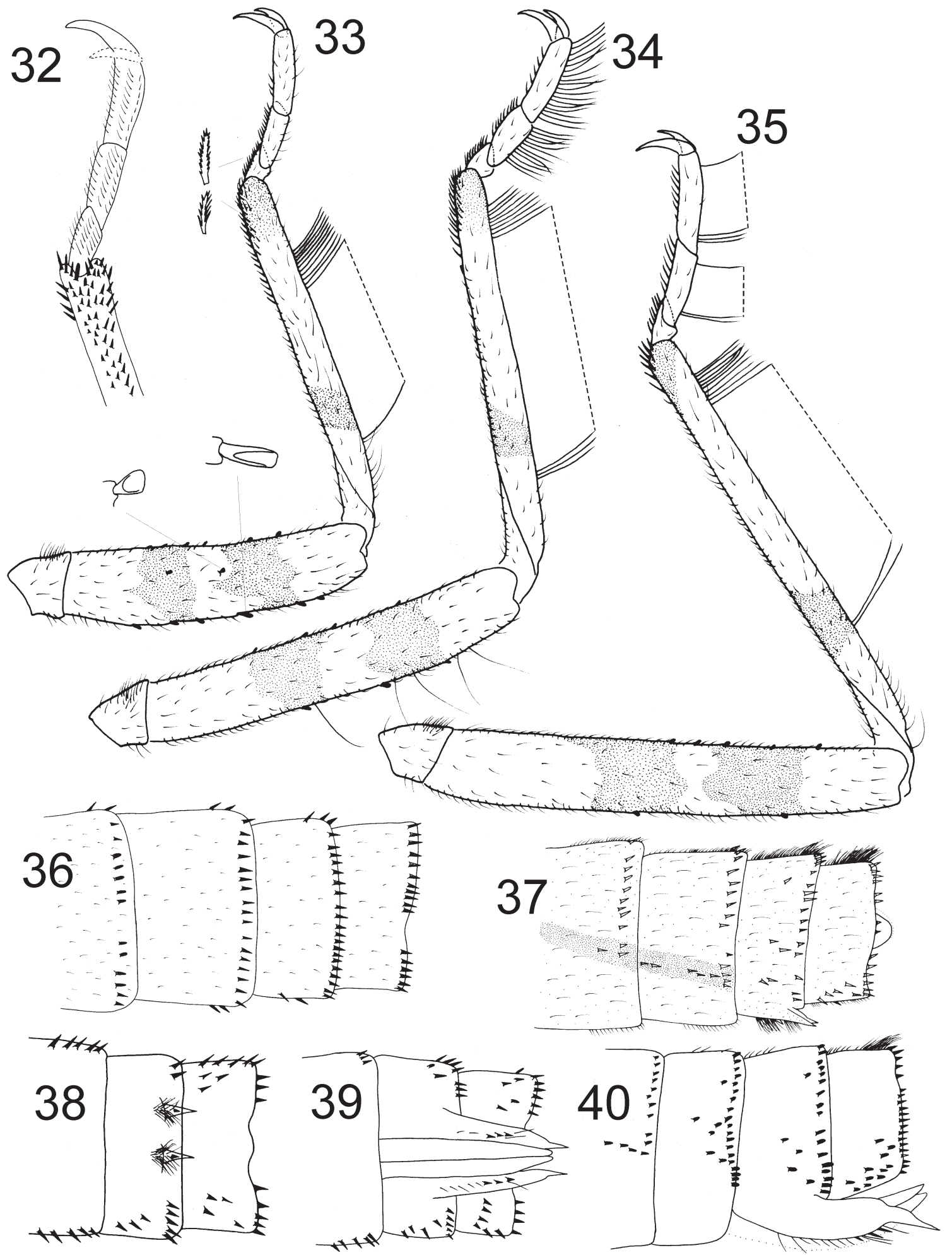

Figures 32-40 - Neoneura confundens, last instar larva: 32, apex of fore tibia and tarsus, ventral view; 33, fore leg, dorsal view; 34, middle leg, dorsal view; 35, hind leg, dorsal view (dotted lines indicate the row of long setae); 36, male abdomen S7-10, dorsal view; 37, male abdomen S7-10, lateral view; 38, male S8-10, ventral view; 39, female abdomen S8-10, ventral view; 40, female abdomen S7-10, lateral view. 
3'. General coloration dark brown; 28-35 setae on the ventral margin of lateral lamella. . . . Neoneura maria

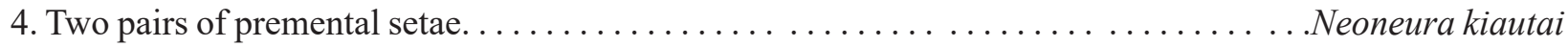

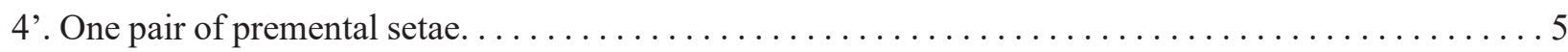

5. S8-10 armed with spines on distal border; ventral border of lateral lamella armed with a row of about 24

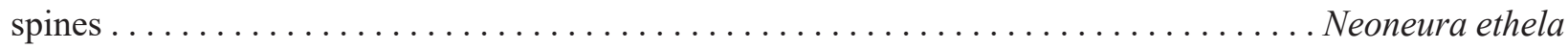

5'. S5 or 6-10 armed with spines on distal border (including lateral carina of segments mentioned); ventral

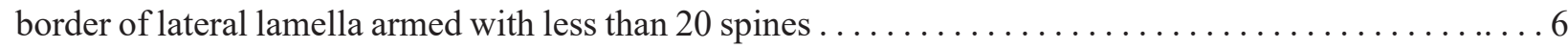

6. Pronotum with lateral projection rounded; lateral lamellae as long as abdomen; ventral border of lateral lamella armed with a row of 19 spines; posterior margin of prementum triangular; ovipositor armed with three spines on ventral margin and surpassing the end of $\mathrm{S} 10 \ldots \ldots \ldots \ldots \ldots \ldots \ldots$ Neoneura joana

6'. Pronotum with lateral projection sharp, lateral lamellae as long as S4-10 together; ventral border of lateral lamella armed with a row of 11-12 spines; posterior margin of prementum rounded; ovipositor only with hair-like setae on ventral margin and reaching the end of $\mathrm{S} 10 \ldots \ldots \ldots \ldots$. Neoneura fulvicollis

\section{DISCUSSION}

The larva of Neoneura confundens can be separated from the other of the genus by the following combination of characters: 1) prementum subtriangular and with one pair of premental setae; 2) 3 to 4 palpal setae present; 3) rounded occipital lobes; 4) femora with two dark bands; 5) all tibiae and tarsi 2-3 with fringed hind margins; 6) spine-like setae on distal margin of S7-10; 7) 26 spine-like setae on the ventral margin of lateral lamella; 8) diagonal and sinuate line separating basal and distal parts of caudal lamella; 9) nodus located at about 1/2 of lamella; 10) lateral lamella 3/4 the length of the abdomen; and 11) apex of ovipositor surpassing apex of S10.

The larva of Neoneura confundens shares with N. aaroni, N. carnatica, N. fulvicolis, N. joana, $N$. maria and $N$. ethela the presence of one pair of premental setae, whereas $N$. kiautai has two pairs. The larva of $N$. confundens, shows tibiae and tarsi hind margin fringed with long setae, as in both Cuban species $(N$. carnatica and $N$. maria). These two species are readily separable from $N$. confundens by the presence of three dark bands on femora (only two in $N$. confundens) and because the fringed margin is present in all tarsi (absent in fore tarsus of $N$. confundens).

\section{ACKNOWLEDGMENTS}

We are thankful to Pablo Pessacq and anonymous reviewers for comments and suggestions. We also thank E. Pero for the material from Santiago del Estero province and A. Elbakyan for bibliography. The following grants partly financed this work: CONICET PIP 845 and PUE 099.

\section{AUTHOR CONTRIBUTIONS}

Both authors collected the material, described and illustrated the specimens, analyzed results and wrote the paper. 


\section{REFERENCES}

ANJOS-SANTOS D, PESSACQ P AND COSTA JM. 2011. Description of the last instar larva of Neoneura kiautai Machado (Odonata: Protoneuridae). Zootaxa 2916(1): 65-68.

DE MARMELS J. 2007. Thirteen new zygoptera larvae from Venezuela (Calopterygidae, Polythoridae, Pseudostigmatidae, Platystictidae, Protoneuridae, Coenagrionidae). Odonatologica 36(1): 27-51.

DE SOUZA LOI, PEPINELLI M AND NEISS UG. 2012. The larva of Neoneura ethela Williamson, 1917 (Odonata: Protoneuridae). Zootaxa 3318: 63-67.

DIJKSTRA K-DB ET AL. 2013. The classification and diversity of dragonflies and damselflies (Odonata). Zootaxa 3703(1): 36-45.

DIJKSTRA K-DB, KALKMAN VJ, DOW RA, STOKVIS FR AND VAN TOL J. 2014. Redefining the damselfly families: a comprehensive molecular phylogeny of Zygoptera. Syst Ent 39: 68-96.

GARRISON RW. 1999. The genus Neoneura, with keys and description of a new species, Neoneura jurzitzai spec. nov. (Zygoptera: Protoneuridae). Odonatologica 28: 343-375.

GARRISON RW, VON ELLENRIEDER N AND LOUTON JA. 2010. Damselfly Genera of the New World. An illustrated and annotated key to the Zygoptera, $1^{\text {st }}$ ed., Baltimore: The Johns Hopkins University Press, 490 p.

GEIJSKES DC. 1954. Notes on Odonata of Surinam VI. The nymph of Neoneura joana Will. Ent News 65: 141-144.

HADLEY A. 2010. Combine ZP software, new version [WWW document]. URL Accessed on May 2013. http://www.hadleyweb. pwp.blueyonder.co.uk/CZP/News.htm

NEEDHAM JG. 1939. Nymphs of the Protoneurine genus Neoneura (Odonata). Ent News 50: 241-245.

PESSACQ P. 2008. Phylogeny of Neotropical Protoneuridae (Odonata: Zygoptera) and a preliminary study of their relationship with related families. Syst Ent 33(3): 511-528.

RODRÍGUEZ JS, GOMEZ D AND MOLINERI C. 2014. New records of Odonata and Ephemeroptera from Northern Argentina. Rev Soc Entomol Arg 73(1-2): 85-88.

VON ELLENRIEDER N AND MUZÓN J. 2008. An updated checklist of the Odonata from Argentina. Odonatologica 37(1): 5568.

WASSCHER MT AND J VAN'T BOSCH. 2013. The true identity of Neoneura bilinearis Selys, 1860, with the synonymy of $N$. gaida Rácenis, 1953, and the description of $N$. confundens sp. nov. (Odonata: Protoneuridae). Zootaxa 3599(1): 19-36.

WATSON MC. 1956. The utilization of mandibular armature in taxonomic studies of anisopterous nymphs. Trans Amer Ent Soc 81: 155-202.

WESTFALL MJ. 1964. Notes on the Odonata of Cuba. Q J Florida Acad Sci 27(1): 67-85.

WESTFALL MJ AND MAY ML. 2006. Damselflies of North American, Revised Edition. Scientific Publishers, Gainesville, FL, $503 \mathrm{p}$. 